\title{
Patrimônio cultural e turismo: tensões contemporâneas
}

Fernando Cesar Sossai* Ilanil Coelho**

Resumo: este artigo tem como objetivo refletir sobre as tensões sociais que se desdobram da aproximação entre patrimônio cultural e turismo, enfocando acontecimentos recentes da cidade de Barcelona. Baseando-nos num conjunto de fontes atinentes a duas importantes regiões turísticas dessa cidade (as zonas monumentais do Parc Güell e da Cidade Velha), buscamos problematizar as formas e os meios pelos quais o patrimônio vem servindo de sustentáculo para contestações e reações à expansão do turismo na região. $\mathrm{O}$ artigo está dividido em três partes. Na primeira, apresentamos uma discussão teórica a respeito de conceitos e ideias que mobilizamos em nossas recentes investigações e que nos auxiliam no debate sobre as disputas e tensões emergentes dos usos turísticos de lugares e bens patrimonializados. Na segunda, procuramos historicizar as políticas que nortearam as mudanças urbanas de Barcelona e que implicaram na patrimonialização e turistificação de objetos e lugares urbanos, bem como as formas com que eles são apropriados para contestar e questionar suas funções na contemporaneidade da cidade. Na última parte, mais do que conclusões, procuramos apresentar algumas hipóteses que poderão subsidiar novas investigações sobre usos do passado e processos de patrimonialização.

Palavras-chave: Patrimônio cultural. Memória. Turismo. Cidade contemporânea. Barcelona.

\footnotetext{
"Professor na Universidade da Região de Joinville (UNIVILLE). Doutorado em Educação pela Universidade do Estado de Santa Catarina (UDESC). E-mail: fernandosossai@gmail.com, https://orcid.org/0000-0002-6757-4151

"** Professora na Universidade da Região de Joinville (UNIVILLE). Doutorado em História Cultural pela Universidade Federal de Santa Catarina (UFSC). E-mail: ilanilcoelho@gmail.com, https://orcid.org/0000-0002-2903-404X
} 


\section{Introdução}

Este artigo resulta do desenvolvimento de um conjunto de investigações empreendidas pelos integrantes do Grupo de Pesquisa Cidade, Cultura e Diferença da Univille (GPCCD) em articulação $\infty$ com pesquisadores vinculados a universidades brasileiras e estrangeiras que se dedicam à identificação, análise, problematização e interpretação dos usos, das apropriações e dos jogos de poder que envolvem o patrimônio cultural nas cidades contemporâneas ${ }^{1}$.

A problemática norteadora do nosso trabalho consiste em, por um lado, perscrutar os múltiplos usos da memória e do patrimônio por parte de grupos sociais que, ao reivindicar seus direitos ao espaço urbano, também inventam criativas formas de se apropriar da cidade. Por outro lado, mas implicada nesse direcionamento, a problemática envolve as novas configurações dos patrimônios culturais, especialmente aqueles reconhecidos pela UNESCO como patrimônios mundiais, a partir dos deslocamentos humanos e dos fluxos que marcam a vida social, a saber, os movimentos migratórios transnacionais e os fluxos turísticos.

Considerando os resultados atingidos com o desenvolvimento de dois projetos de pesquisa ${ }^{2}$, neste artigo procuramos refletir sobre as tensões sociais que se desdobram da aproximação entre patrimônio cultural e turismo, particularmente em cidades cujos agentes públicos e privados historicamente empreenderam esforços de gestão visando converter bens patrimoniais em produtos economicamente rentáveis. Nesse sentido, na primeira parte do texto, apresentamos uma discussão teórica a respeito de alguns conceitos e ideias que mobilizamos em nossas recentes investigações ${ }^{3}$ e que nos auxiliam no debate sobre as disputas e tensões emergentes dos usos turísticos de lugares ou bens patrimonializados, em especial sobre os efeitos locais decorrentes de estratégias voltadas a tornar a cidade uma mercadoria atrativa para competir no denominado "mercado internacional de cidades".

$\mathrm{Na}$ segunda parte do texto, promovemos uma reflexão acerca dos usos turísticos do patrimônio cultural de Barcelona para, em seguida, problematizar as formas e os meios pelos quais o patrimônio da cidade vem, no tempo presente, servindo de sustentáculo 
para contestações e reações à expansão desenfreada do turismo internacional na região. Trata-se de um estudo de caso que faz uso de diversas fontes coletadas entre os anos de 2015 e 2016 por pesquisadores do GPCCD que tiveram como campo de investigação duas importantes regiões turísticas de Barcelona, quais sejam, as zonas monumentais do Parc Güell e da Cidade Velha. Especificamente nessa seção do texto, nossas discussões estão fundamentadas em fichas de análise especialmente desenvolvidas, conforme tipologia e suporte (imagens, reportagens e documentos oficiais), decorrentes do trabalho interdisciplinar permanentemente em construção no âmbito do GPCCD.

$\mathrm{Na}$ terceira e última parte, finalizamos o escrito com algumas considerações a respeito dos desafios teórico-metodológicos de se pesquisar as interfaces entre práticas urbanas que usam o patrimônio cultural para reivindicar o direito a ele e à cidade.

\section{Cidade contemporânea, patrimônio cultural e turismo}

Que o patrimônio seja uma construção social significa, antes de tudo, que ele não existe na natureza, que não é algo dado, nem mesmo um fenômeno social universal, já que não se produz em todas as sociedades humanas, nem em todos os períodos históricos; também significa, correlativamente, que é um artifício, concebido por alguém (ou no decorrer de algum processo coletivo), em algum lugar e momento, para certos fins, e implica, finalmente, que é ou pode ser historicamente mutante, de acordo com novos critérios ou interesses que determinam novos fins em novas circunstâncias (PRATS, 1997, p. 19, tradução nossa).

A epígrafe nos remete a três pressupostos básicos que acolhemos e que nos auxiliam a compreender o patrimônio como um constructo social. Em primeiro lugar, a patrimonialização de um bem decorre de escolhas e intenções de sujeitos ou grupos num determinado momento e lugar para desempenhar determinadas 
funções e finalidades. Por isso, os patrimônios devem ser tomados não como pontos de partida para explicar as ações e intenções que os constituíram, mas como efeitos dessas ações e intenções. Tal pressuposto implica abordá-los como resultante de redes e arranjos de poder que, em dada configuração histórica, os produzem como objetos e os materializam como realidade patrimonial.

Contudo, numa perspectiva histórica, analisar, problematizar e interpretar um patrimônio como construção social não é tarefa fácil, visto que as lógicas ordenadoras e institucionais envolvidas em sua "transubstanciação simbólica de uma coisa (prédio, igreja, paisagem) em outra (patrimônio cultural)" (COELHO; RADUN, 2016, p. 30) não nos auxiliam na elaboração crítica de suas supostas "distorções" inscritas e observáveis quer no cotidiano urbano quer operadas por novos arranjos de poder. Concordando com Prats (1997), a legitimidade do patrimônio também é alcançada por esquecimentos e até mesmo apagamentos da historicidade de sua instauração. Isso quer dizer que em novas circunstâncias, e a cada nova circunstância, o patrimônio torna-se ele próprio circunstanciável, isto é, aberto a novos critérios e interesses para determinar ou alterar seus fins e funções.

Sobre isso, Nathalie Heinich (2014) oferece-nos uma interessante reflexão. Sugere a autora que, ao estudarmos a história do patrimônio, não podemos nos valer de concepções apriorísticas sobre o que ele seja, mas "compreender o que os atores entendem por patrimônio no momento em que utilizam esse termo ou quando realizam as operações que produzem tal qualificação". Valendose do pensamento de Foucault, Heinich sugere que estudemos o patrimônio a partir do que chama "função-patrimônio", ou seja, "o estado no qual são mergulhados os objetos na medida em que são submetidos a certos tipos de operação (semântica, jurídica, cognitiva, gestual etc.)" (HEINICH, 2014, p. 5).

Isso nos dá pistas para problematizar os atos e discursos que, atualmente, visam aproximar ou desvincular o patrimônio de finalidades turísticas e urbanísticas. Por um lado, observamos que projetos turísticos ou de intervenção urbana que mobilizam o patrimônio como recurso presente e disponível para alcançar objetivos econômicos, mercadológicos ou mesmo de desenvolvimento 
local, operam com ideias vagas e imprecisas sobre o que o constitui como patrimônio, os valores a ele atribuídos, quando, por quem, para quem e para que foi inventado. Por outro lado, observamos argumentos em defesa do patrimônio, geralmente provenientes de alguns especialistas da área ou de admiradores, que se baseiam na importância da história de sua constituição para demonstrar e explicar sua pertinência e relevância para a atualidade. Dito de outro modo, ao buscarem desvelar e disseminar a trajetória temporal de um dado patrimônio para defender sua proteção, acabam por reforçar uma concepção essencialista de patrimônio, tornando-o algo que também se apresenta como um recurso presente e disponível para salvaguarda, mas para ser protegido de apropriações sociais tidas como incompatíveis em relação à história e aos valores seminais que representa.

Diante disso, cabe-nos avançar na reflexão, cientes de que para abordar criticamente as relações entre patrimônio e turismo não bastam posições que oponham o caráter dinâmico das funções-patrimônio do seu caráter histórico. Conforme explicado por Prats, se a invenção do patrimônio nos remete aos discursos e atos que o instauram, a construção social do patrimônio nos remete aos processos de sua legitimação. Diz ele: "a invenção, para arraigar e se perpetuar, necessitará 'converter-se' em construção social, quer dizer, alcançar um mínimo de consenso" (PRATS, 1997, p. 21, tradução nossa). É nesse jogo de invenção, construção social e legitimação de patrimônios que ganha relevo o que o autor denomina de processo de ativação patrimonial.

Segundo Prats, a ativação patrimonial advém de fontes de autoridade que atribuem significados ao patrimônio, acionando elementos de um repertório cultural prévio, mais amplo e direta ou indiretamente compartilhado. Mais precisamente, essa ativação se dá por meio de discursos que se referem a "uma" identidade, ou melhor, que pretendem torná-la "a" identidade de uma nação ou de um território. Assim, se o fator determinante do patrimônio é "seu caráter simbólico, sua capacidade para representar simbolicamente uma identidade" (PRATS, 1997, p. 22, tradução e grifo nosso), a ativação patrimonial faz com que um bem cultural e o discurso identitário que o torna sua representação sejam justapostos 
e adquiram um caráter de sacralidade. Daí o fato dos patrimônios culturais parecerem fluir por si só em diferentes tempos e espaços e que a força deles independe dos diferentes usos que são perspectivados num dado presente.

Nas palavras do historiador francês Michel de Certeau (1996), ao fazermos emergir das "coisas antigas [...] o que pode ser chamado de "patrimônio", as "velhas pedras renovadas" da cidade são transmutadas em "lugares de trânsito entre os fantasmas do passado e os imperativos do presente”. Não mais limitados pelas suas formas geográficas, os patrimônios inventados e disponibilizados à fruição de moradores e turistas que circulam pelas cidades contemporâneas assumem "forma histórica", supostamente habilitada à permutação entre "memórias estranhas", ao passo que se transfiguram em lugares de fronteira que "separam as épocas, os grupos e as práticas" (DE CERTEAU, 1996, p. 194-195).

No caso de Barcelona, uma questão formulada por Michel de Certeau (1996) parece chave para compreendermos como, historicamente, diferentes agentes públicos e privados foram aproximando patrimônio cultural e turismo: no contexto das décadas de 1980 e 1990, "depois de haver projetado a cidade futura, será que se começou a imaginá-la no passado, como um espaço de viagens nela mesma, uma profundidade de histórias?”. Ou seja, em Barcelona, as estratégias de projeção de "novos espaços urbanos transformaram-se aos poucos em reabilitação de patrimônios”, inventando, ativando e interditando passados palatáveis para degustação turística? (DE CERTEAU, 1996, p. 189).

Para os propósitos desta escrita é necessário, por fim, apresentarmos alguns delineamentos sobre o que entendemos por cidade contemporânea. Em primeiro lugar, tomando como pressuposto a noção proposta por De Certeau (1996), o espaço urbano é um lugar praticado e sua existência consiste no conjunto dos movimentos que o animam, ou seja, na multiplicidade de práticas sociais que cotidianamente o produzem. Quando utilizamos o termo cidade contemporânea, nos referimos a uma maneira própria de ver e problematizar o urbano, sob a qual incide uma abordagem específica de estudo das transformações das cidades a partir da segunda metade do século XX. Isso porque, na contemporaneidade, os movimentos 
que animam o espaço urbano e que lhe dão existência se desenrolam em diálogo com vivências e subjetividades entremeadas por disjunções, superposições e complexidades de fluxos de tecnologias, finanças, imagens, informações e pessoas (COELHO, 2011). Seria, pois, no seu próprio movimento que a cidade contemporânea, na perspectiva de Gupta e Ferguson (2000), emerge como uma nova configuração. Diante da dinâmica dos entrecruzamentos de fluxos globais e da própria fluidez da vida urbana, tais autores sugerem que o estudo da cidade deve levar em conta tanto a "interseção entre seu movimento específico em um sistema de espaços hierarquicamente organizados e sua construção cultural como comunidade ou localidade" quanto os processos de identificação dos citadinos, para além da ideia de isomorfismo entre espaço, lugar e cultura (GUPTA; FERGUSON, 2000, p. 32).

Assim, no próximo item deste artigo nos dedicamos a refletir sobre as tensas relações entre patrimônio cultural e turismo em Barcelona, buscando lançar questões que possam abrir possibilidades críticas diante de explicações que, muitas vezes, avaliam os termos dessas relações como dicotômicos, excludentes e inconciliáveis, independentemente da historicidade, dos lugares e das circunstâncias que lhes movem. Isso implica em abordarmos essa cidade como localidade específica e singular, problematizando as imbricações dos atos de patrimonialização e de turistificação, deflagrados por projetos urbanísticos, com as experiências sociais que produzem cotidianamente a cidade, as quais, física e simbolicamente, podem ser apreendidas na materialidade dos lugares, nas formas de suas sociabilidades e nos processos pelos quais os sentimentos urbanos de pertencimento e de recusa se manifestam (COELHO, 2011, p. 29). Do nosso ponto de vista, é nesse percurso teórico que Barcelona pode, ao mesmo tempo, abrir-se como um palco de experiências humanas complexas que se tornam comuns e compartilháveis à medida que a identificamos como uma, dentre muitas outras, cidade contemporânea.

Metodologicamente, além dos escritos de gestores públicos e estudiosos que apresentaram seus diagnósticos e posicionamentos, travando debates acerca das transformações da cidade catalã nas décadas de 1980 e 1990, recorremos a uma variedade de fontes 
escritas e iconográficas produzidas por órgãos governamentais, da imprensa e de gestão público-privada de turismo e cultura. Algumas dessas fontes estão em suporte digital. As fontes iconográficas também abrangeram material de divulgação, coletado durante nossa permanência em Barcelona, e registros fotográficos, interligados aos nossos registros de observação e vivência na cidade.

Para melhor organizar, assim como para facilitar nosso trabalho de análise e de interpretação, todas as fontes foram digitalizadas e inseridas no Banco de Dados do GPCCD (criado, alimentado e acessado pelos pesquisadores do grupo), que possui um sistema de busca por palavras-chave e períodos. Desse modo, procedemos a um registro específico de cada fonte, contendo: tipologia, proveniência, referência, resumo e fichas de análise. Destaca-se que, no âmbito do GPCCD, as fichas de análise são elaboradas pelos pesquisadores que se valem de qualquer fonte disponível no Banco de Dados. Por isso, não obedecem a um modelo único e são de número variável. Contudo, devem indicar as razões pelas quais foram selecionadas, as questões que suscitam e a metodologia de análise. Consideramos que as fichas de análise são instrumentos poderosos para nossas práticas investigativas que queremos que sejam cada vez mais colaborativas e implicadas em trocas teóricas e metodológicas entre, ou melhor, interdisciplinares. Para os propósitos do próximo item, incorporamos ao texto algumas imagens, com o intuito de fornecer ao leitor referências visuais para as questões evocadas, analisadas e por nós estudadas.

\section{Barcelona contra o turismo?}

No princípio dos anos 1990, Barcelona foi assim caracterizada por Jordi Borja ${ }^{4}$, um intelectual e gestor público bastante envolvido com o replanejamento da cidade para atender às exigências de infraestrutura urbana para os Jogos Olímpicos de 1992:

A simples contemplação do plano da cidade mostra três realidades físicas bem diferenciadas: a) a Cidade Antiga (a única até meados do século XIX) e o porto; b) o Ensanche 
moderno (segundo o Plano Cerdá) que configura a centralidade do final do século XIX até os anos 1980; c) os bairros que foram a periferia até meados do século XX. Esses três tipos de tramas urbanas padeciam tanto de déficits específicos (degradação e congestionamento das duas primeiras e debilidade da urbanização - equipamentos e serviços - na última) como de insuficiente articulação entre si (BORJA, 1995, p. 3, grifo do autor, tradução nossa).

Segundo o autor, após 1992, a "mudança mais espetacular da Barcelona dos 1980”, sem dúvida, foi a interconexão das numerosas regiões da cidade em uma "escala" nunca antes vivida por sua população. Em seu escrito, Borja não se furtava à defesa dos êxitos logrados pelo poder público ao decidir tornar Barcelona a cidade dos Jogos Olímpicos de 1992. Aliás, teria sido a realização do Evento que fez emergir novas políticas de organização e uso da cidade, incidindo diretamente sobre a melhoria dos modos de vida da população. Em suas palavras:

A definição de novas centralidades se baseia em uma iniciativa pública de caráter inovador (como requalificação de solo); urbanizador (como a criação de espaços públicos de qualidade ou melhoria da acessibilidade) e construtor (como é promover a instalação de um museu ou de um equipamento universitário). Então, também se exige um desenvolvimento privado (como os derivados do plano de hotéis construídos a partir da celebração dos Jogos Olímpicos) ou grandes operações terciárias mistas de comércio e escritórios (como as vinculadas à construção das áreas olímpicas) combinadas com moradias (BORJA, 1995, p. 7, tradução e grifo nosso).

Da perspectiva de Borja, às portas dos anos 1990, não havia como negar que Barcelona havia melhorado após os Jogos Olímpicos: o futuro da cidade havia sido antecipado; o progresso da urbe havia se adiantado. Conforme pensava o gestor, à pergunta "como pôde transformar-se em tão pouco tempo?" só se admitia 
uma resposta: "a transformação da cidade se atribui, sobretudo, aos Jogos Olímpicos de 1992. Sem dúvida alguma, as grandes realizações de infraestrutura que se realizaram no período 1987-1992 levariam duas, três ou quatro vezes mais tempo sem os Jogos” (BORJA, 1995, p. 7, tradução nossa).

Não havia como negar: no início da década de 1990, os exemplos dessa fase de acelerado desenvolvimento urbano saltavam aos olhos de qualquer pessoa que circulasse por Barcelona:

O Porto Velho convertido em uma zona de passeio e ócio, de conexão com e de visibilidade do mar, conectado com a Vila Olímpica e à cidade antiga (p. 3); A progressiva reabilitação da cidade antiga: praças e ruas para pedestres, fachadas e pequenas moradias, renovação do pequeno comércio, equipamentos culturais, melhoria de serviços básicos (saneamento e fluviais), presença da polícia. [...] A revalorização do Ensanche mediante uma política de contenção da terceirização e do automóvel particular, de recuperação ou criação de espaços públicos ou coletivos (passeios e praças, jardins e quadras) e de realce de seus valores arquitetônicos e culturais (por exemplo, o modernismo); a remodelação dos bairros periféricos populares, especialmente por meio de uma política de melhoria da acessibilidade, de espaços públicos estratégicos (praças e passeios, parques) e de equipamentos sociais, culturais e desportivos, assim como algumas operações pontuais de moradia. Essas atuações contêm sempre elementos de "monumentalização" dos bairros (BORJA, 1995, p. 7, tradução nossa).

Com mais ou menos detalhes, os exemplos citados por Borja sinalizam o massivo investimento público-privado na remodelação da estética urbana de Barcelona com o objetivo de melhor posicioná-la em meio ao competitivo mercado mundial de cidades ${ }^{5}$. Em sintonia com a noção de "marketing de cidades" - um "conceito que ganhou autoridade na década de 1980” -, a ideia de Borja parecia ser a de agenciar Barcelona com o propósito de incentivar o consumo da urbe por diferentes públicos (OCKE; IKEDA, 2014, p. 671). As 
razões para se investir em projetos que reformulassem a estética da cidade foi assim enunciada pelo gestor:

[...] a estética urbana acentua os elementos diferenciais e atrativos da cidade. É um elemento fantástico de city marketing. $\mathrm{O}$ ambiente urbano, a oferta cultural e a plástica ou imagem da cidade são atualmente fatores indispensáveis para atrair visitantes, turistas, congressistas e investidores. É, além disso, [...] um bom investimento (BORJA, 2015, p. 14, tradução nossa).

Em termos concretos, a melhoria da estética da cidade, para Borja, não significava submeter o cotidiano urbano à "moda ou aos caprichos dos profissionais” encarregados de planejá-lo. De fato, a preocupação com a estética urbana de Barcelona reclamava projetos governamentais que expressassem o "cuidado com o design do mobiliário, com a imagem da cidade", que atentassem para "todas as expressões artísticas ou culturais da cidade”. Nessa perspectiva,

Os monumentos e as esculturas (pelo que representam e pelo prestígio de seus autores), a beleza plástica e a originalidade do design das infraestruturas e dos aparelhos urbanos (como algumas pontes, estações reabilitadas, arenas esportivas etc.) ou o cuidado com a paisagem das praças e jardins proporcionam dignidade à cidadania, fazem a cidade mais visível e reforçam a identidade, inclusive o patriotismo cívico de sua gente. A estética urbana constrói referenciais culturais indispensáveis aos cidadãos para apropriarem-se da cidade (BORJA, 2015, p. 14-15, tradução nossa).

Caso emblemático do estímulo à estetização de bens considerados estratégicos ao desenvolvimento da cidade foi a Campanha Barcelona ponte guapa (Barcelona põe-te bela). Iniciada pela Prefeitura em 1985, a campanha consistia numa "grande operação promocional" com o objetivo de "encontrar investidores para reabilitar edifícios significativos", bem como oferecer "apoio econômico" aos cidadãos que se interessassem por "pintar fachadas, renovar [...] e 
reabilitar suas moradias e comércios”. Em seus primeiros dez anos, a Campanha já contava com o total de "5.000 adesões" (BORJA, 1995, p. 15, tradução nossa). E, até 2009, ano em que a Campanha foi encerrada", tinha sido "empreendida a reabilitação de 27.000 edifícios do total de 86.744 que a cidade possuía”. Isto é, entre 1985 e 2009, "na prática, significou que um em cada três blocos habitacionais da capital catalã passou por algum processo de reforma, reabilitação ou melhoria”. Durante os 24 anos da Campanha, em termos globais (verbas públicas, fundos privados, recursos de particulares), as obras em "edifícios alcançaram quase 700 milhões de euros", sendo 100 milhões oriundos de "investimentos públicos" (ARBOLÍ, 2010).

Embora as reflexões de Jordi Borja sejam relevantes para conhecermos como, no contexto dos Jogos Olímpicos de 1992, a Prefeitura de Barcelona armou estratégias público-privadas direcionadas à reconfiguração de patrimônios e de outros bens culturais considerados relevantes à almejada reabilitação da cidade, a bem da verdade é que elas são silenciosas em relação às tensões e aos conflitos urbanos gerados quando implementadas.

Numerosos estudos ${ }^{7}$ evidenciam que, à época, os dispositivos criados pela Prefeitura para reabilitar zonas históricas eram ilógicos e, por vezes, violentos. O geógrafo e historiador Horacio Capel ironiza os resultados das intervenções do poder público no centro histórico de Barcelona dizendo que elas pareciam ter sido realizadas utilizando "brocha grossa" ao invés de um "pincel fino: no lugar de tentar fazer uma delicada obra de marchetaria, se preferiu atuar com marteladas". E completa: no transcurso da década de 1980 e início dos anos 1990, "não se pode dizer que as intervenções realizadas no centro histórico de Barcelona sejam um modelo para ninguém” (CAPEL, 2009, p. 63, tradução nossa).

As principais críticas desse autor foram desferidas contra "políticos e técnicos" que, nos "últimos 25 anos" (1980) atuavam com total "falta de respeito à história de Barcelona", inclusive autorizando a destruição de "edifícios com presença de importantes elementos medievais [...]" em favor da construção de "ridículos edifícios que seguem a moda pós-moderna” (CAPEL, 2009, p. 66, tradução nossa). Nesse âmbito, Capel via com desconfiança o trabalho de 
certos colegas que manifestavam uma obsessão pela novidade para "deixar sua marca pessoal" na estética da cidade. Para ele, "unida à falta de sensibilidade histórica [...], tais arquitetos incorrem, muitas vezes, numa total desvalorização do patrimônio existente" (CAPEL, 2009 , p. 67, tradução nossa). Segundo o autor, há casos famosos em relação às abruptas intervenções público-privadas no patrimônio de Barcelona:

[....] parece-me totalmente desacertada a estratégia seguida para a ampliação do Museu Picasso, na Rua Montcada, uma intervenção mal planejada e realizada. Não apenas modificou-se gravemente, e às vezes arbitrariamente, a estrutura dos palácios góticos ali existentes, mas também se destruiu alguns dos séculos XIII e XIV, assim como parte da trama de Vilanova de Barcelona, a primeira expansão ortogonal da cidade, desenhada no século XX: as torres falsas de concreto construídas na parte posterior do Museu são, além disso, um atentado ao bom gosto. Também se deve criticar a destruição do mercado neoclássico de Santa Catarina, para construir um moderno edifício que haveria seguramente dignificado um polígono de moradias, mas está totalmente fora de lugar em um setor de grande densidade histórica (CAPEL, 2009, p. 67, tradução nossa).

O estudo de Capel (2009) em nenhum momento nega que Barcelona seja uma cidade historicamente dinâmica, cosmopolita e contemporânea. $\mathrm{O}$ desconforto do autor reside no caráter autoritário com que algumas mudanças foram impostas aos moradores das localidades afetadas, mudanças essas que mutilaram e/ou descontinuaram ícones urbanos que sinalizavam a existência de passados milenares em Barcelona. A própria presença de moradores nas regiões impactadas pela tomada de decisão do gestor público, vez ou outra, foi desconsiderada. Desse ponto de vista, Capel sugere que, antes de fabricar e comercializar patrimônios ou outros bens culturais para atender aos desejos de turistas consumidores da cidade, gestores públicos e empresários deveriam, primeiro, "refletir muito antes de tomar suas decisões. E, discutir com as pessoas, com os 
cidadãos", indo além da "opinião dos especialistas" (CAPEL, 2009, p. 68, tradução nossa).

Esposando as análises de Capel, Núria Pascual-Molinas e Ramon Ribera-Fumaz (2009) aludem à violência perpetrada pelo poder público contra moradores de Barcelona que habitavam, no começo da década de 1990, regiões com grande quantidade de bens considerados patrimônio cultural. Contam-nos os autores que a Cidade Velha, um Distrito que "possuía a maior quantidade de atrações e atividades turísticas de Barcelona", foi acometida por um "contínuo processo de gentrificação, afetando profundamente os residentes" que insistiram em permanecer vivendo na região (PASCUAL-MOLINAS; RIBERA-FUMAZ, 2009, p. 180, tradução nossa). De acordo com eles, as intervenções na Cidade Velha se expandiram de maneira tão brutal que a Prefeitura chegou a subdividir o "Distrito em cinco áreas: Raval Nord, La Ribera-Born, Raval Sud e Santa Catarina/Sant Pere, Gòtic e Barceloneta" (Figuras 1 e 2) (PASCUAL-MOLINAS; RIBERA-FUMAZ, 2009, p. 183, tradução nossa).

\section{Figura 1 - Mapa do perímetro de Barcelona com indicação do Distrito da Cidade Velha}

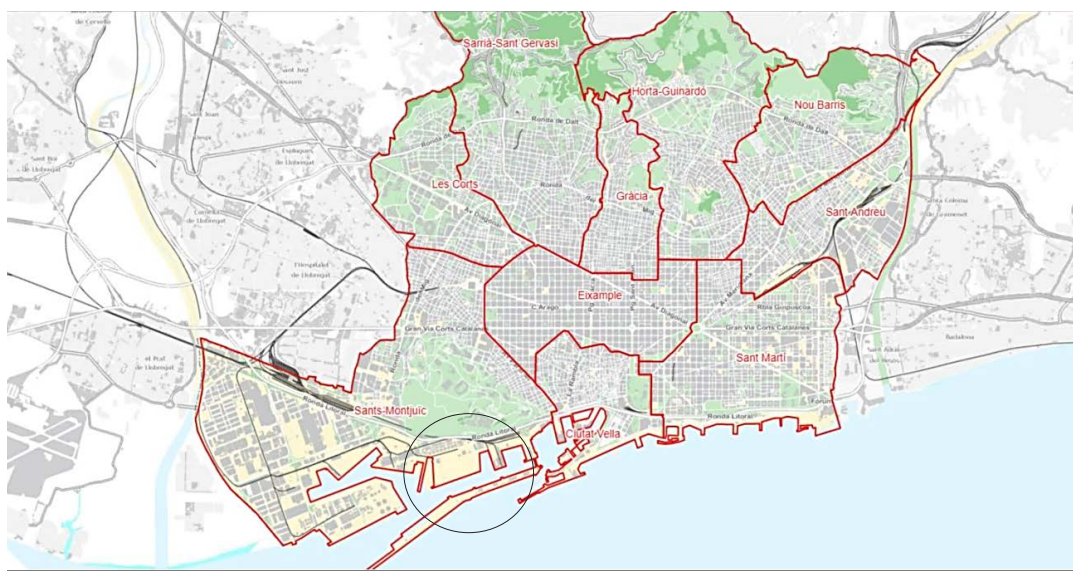

Fonte: Plànol BCN. Disponível em: 〈https://w33.bcn.cat/planolBCN/ca/guia/ angle/44.4/position/428143,4583440/>. Acesso em: 10 nov. 2017. 
Figura 2 - Representação das cinco áreas do Distrito da Cidade Velha

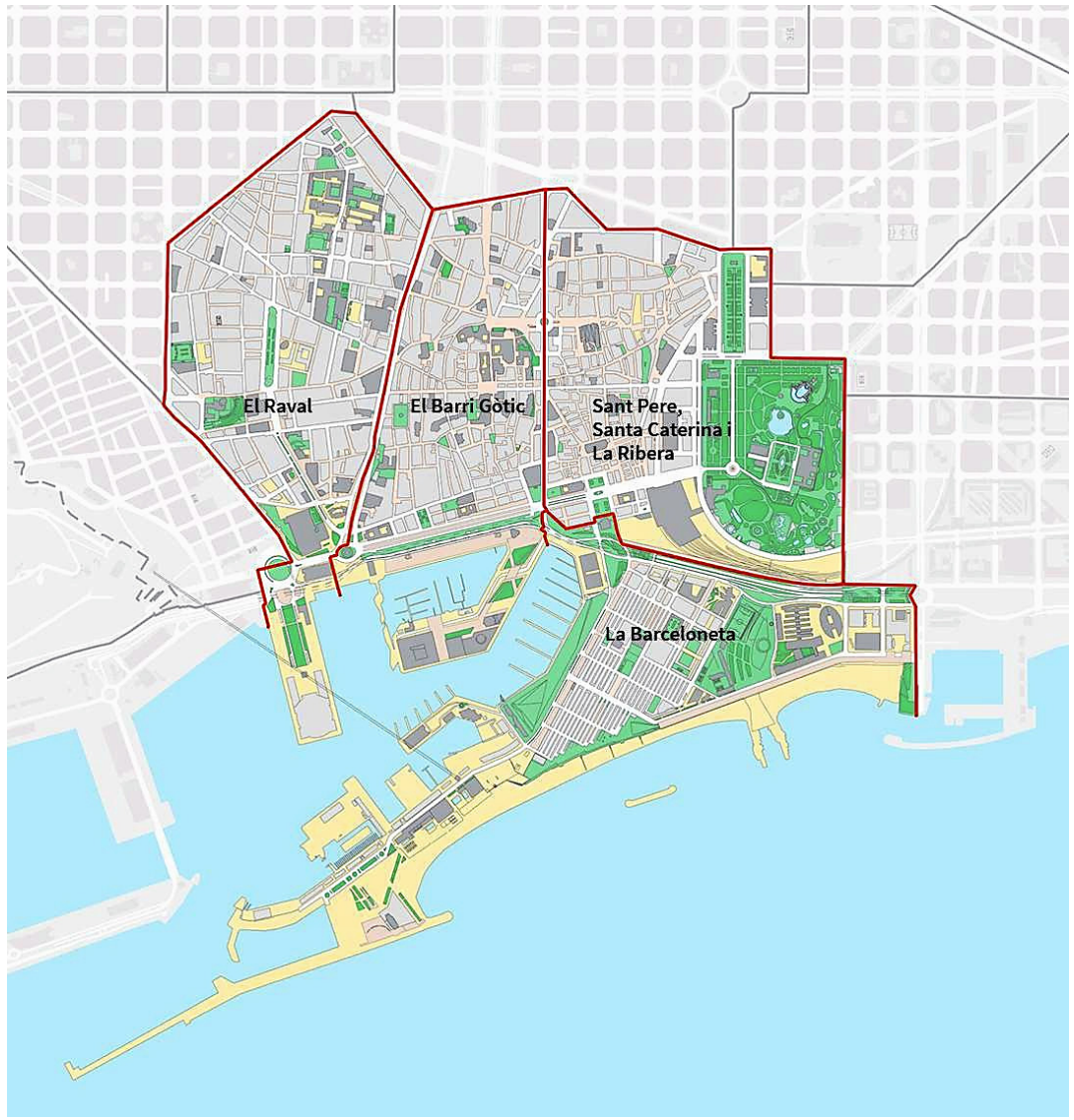

Fonte: El Districte de Ciutat Vella. Disponível em: $\langle$ http://ajuntament.barcelona. cat/ciutatvella/article/el-districte-de-ciutat-vella〉. Acesso em: 10 nov. 2017.

Entre outros argumentos que supostamente justificavam tal intervenção, estava a defesa da "melhoria do padrão de vida" dos moradores, a "assepsia do local em relação à presença de traficantes de drogas e à prostituição", a "reinserção do Distrito no circuito cultural, turístico e comercial da cidade”. Quando transposta à ação, a operação urbana na Cidade Velha foi bastante agressiva. Só da região de Santa Catarina, cerca de "2.000 moradores foram 
deslocados para áreas longínquas e 1.078 moradias foram demolidas, incluindo 13 edifícios catalogados como patrimônio arquitetônico". No Raval, "500 edifícios foram demolidos de 1980 a 2002, 4.200 apartamentos foram perdidos e 2.725 novas habitações foram construídas, das quais apenas 1.245 foram fornecidas pela administração pública” (PASCUAL-MOLINAS; RIBERA-FUMAZ, 2009, p. 183184, tradução nossa).

Deixando ainda mais complexo esse cenário, nos anos 1990, tornou-se comum que jovens, estudantes e migrantes vindos de diferentes partes do mundo passassem a residir na Cidade Velha. Só para se ter uma ideia, entre 1990 e 2005, da população total do Distrito (111.290 habitantes), 37\% eram estrangeiros (41.177 pessoas). Frente àquelas intervenções, os "não proprietários tinham poucos direitos" sobre os imóveis que habitavam. Os próprios proprietários "receberam valores muito baixos" pelos seus imóveis, gerando um "forte descontentamento e desconfiança perante as autoridades, principalmente em razão das expropriações”. Da perspectiva de Pascual-Molinas e Ribera-Fumaz, como saldo do processo de "limpeza social antes das Olimpíadas de 1992" e da "redescoberta da Cidade Velha" enquanto "área de atração turística", várias partes do Distrito foram gentrificadas. Houve aumento no preço dos aluguéis; construíram-se novos edifícios para oferecimento de serviços turísticos de hotelaria, gastronomia e hospitalidade; modificou-se o perfil comercial da região, gerando a diminuição do número de lojas e supermercados populares (PASCUAL-MOLINAS; RIBERAFUMAZ, 2009, p. 184, tradução nossa).

Seguindo pelas pistas deixadas por De Certeau (1996, p. 196), não é equivocado dizer que, durante as décadas de 1980 e 1990, as transformações de Barcelona espelharam uma espécie de "economia da restauração" que tendeu a separar dos lugares as pessoas que neles viviam. Nesse âmbito, agentes públicos e privados atuaram com o objetivo de garantir a substituição dos destinatários do patrimônio da cidade. Á época, estratégias oficiais voltadas à reabilitação do urbano já não diziam "mais respeito aos objetos restaurados, mas aos beneficiários da restauração" (DE CERTEAU, 1996, p. 195). Nesses termos, os projetos de reabilitação urbanística de Barcelona culminaram em uma tentativa de "restauração social", segundo a 
qual era preciso mudar o "terreno deteriorado" em favor de sua exploração econômica (DE CERTEAU, 1996, p. 196).

Em se tratando da Cidade Velha, os projetos levados a cabo pelo poder público nunca se limitaram a meras intervenções voltadas à melhoria da infraestrutura urbana. Em parceria com empresários, desde o começo dos anos 1980, já se manifestava a intenção de retirar das mãos dos moradores os imóveis que seriam futuramente renovados, bem como assegurar que as edificações respondessem às demandas do mercado de negócios turísticos, particularmente os desejos de consumo da cidade por parte duma clientela considerada economicamente mais interessante. Embora não aborde especificamente as transformações urbanas de Barcelona, as palavras de Michel de Certeau podem ser tomadas como uma síntese profícua a respeito do que analisamos até aqui: "a restauração dos objetos vem acompanhada de uma desapropriação dos sujeitos” (DE CERTEAU, 1996, p. 196).

Contemporizando essas discussões, não restam dúvidas de que, ao longo das últimas três décadas, a associação entre patrimônio cultural e turismo foi economicamente rentável para a cidade de Barcelona, assim como para a Espanha como um todo. A título de ilustração, vale mencionar que, segundo dados do Ministério da Energia, Turismo e Agenda Digital da Espanha, em 2016, o número de turistas que circularam pelo país foi de 75,3 milhões, em um Estado Nacional cujo número de habitantes era de 46,5 milhões. De acordo com Álvaro Nadal (gestor responsável pelo referido Ministério), em 2016, os "turistas estrangeiros gastaram 77 bilhões de euros", perfazendo o "gasto médio, por turista, de 1.023 euros e o gasto médio diário de 138 euros" (NADAL apud LEDO, 2017). Só na Catalunha - região que mais recebeu turistas em 2016 - atingiu-se a soma de 17 milhões de visitantes. Em 2017, foram batidos todos os recordes em relação à presença de turistas na Espanha. Segundo dados do Instituto Nacional de Estatística (INE), nesse ano, "82 milhões de turistas viajaram à Espanha", gastando no país " 87 milhões de euros, isto é, 12,4\% a mais que em 2016" (INE, 2018, p. 1). Novamente, a Catalunha foi principal destino dos estrangeiros: "18,2 milhões de turistas internacionais" visitaram a região, representando um "aumento de 6,1\%" se comparado ao ano 
anterior (INE, 2017, p. 50). Em relação a Barcelona, os números são ainda mais impressionantes: em 2016, 8 milhões de turistas visitaram uma cidade de aproximadamente 1,6 milhão de habitantes (MARINHO, 2017). No ano seguinte, conforme dados do Observatório de Turismo de Barcelona, as cifras foram ainda maiores: "12,07 milhões de turistas" estiveram na cidade para apreciar, "majoritariamente, a Sagrada Família e o Parc Güell” (EUROPA PRESS, 2018).

No topo da lista de produtos disponibilizados ao consumo turístico, encontram-se dois patrimônios ativados como made in Barcelona. O primeiro: o patrimônio legado à cidade pela tríade artística Antoni Gaudí (1852-1926), Pablo Picasso (1881-1973) e Joan Miró (1893-1983). Além de obras internacionalmente conhecidas e expostas em museus e centros culturais destinados à valorização da memória de Gaudí, Picasso e Miró, a própria estética da cidade é apresentada em sites e peças publicitárias como um produto turístico singular. A arquitetura, o mobiliário urbano, as praças, os parques, os caminhos públicos, os edifícios residenciais... Enfim, os setores público e privado historicamente investiram na fabricação de uma imagem de cidade sensível à arte e que propicia ao turista a interação com bens culturais elaborados a partir da genialidade daqueles artistas.

Em segundo lugar, o consumo do suposto estilo de vida da localidade é o produto formatado para a fruição do turista. Numerosas e diversificadas atividades de lazer e diversão corporificam a "alma catalã” que, apesar de suas diferentes expressões, é divulgada como uma espécie de modo ibérico-mediterrâneo de desfrutar do mundo: festas populares, serviços de gastronomia, atrativos de uma vida noturna cosmopolita e o estilo informal da zona de praias (especialmente os badalados balneários mediterrâneos). Além disso, adjetivada como sensível e solidária para com as diferenças culturais, a população é embalada e anunciada por essas características comuns, buscando fazer de Barcelona a cidade que se abre naturalmente aos turistas.

Contudo, interpondo-se ao empacotamento turístico da cidade, práticas de contestação tornaram-se recorrentes em Barcelona no 
período pós-olímpico. Por meio de diversificadas organizações (Associações de Vizinhos, Assembleia de Bairros por um Turismo Sustentável, Coletivos Okupa, entre outros movimentos sociais), os moradores da cidade vêm se opondo e demonstrando suas insatisfações em relação ao aumento exponencial do número de turistas na região.

O conjunto de imagens apresentadas a seguir evidencia o desconforto dos moradores de Barcelona em relação à expansão do turismo na cidade. Nelas podemos observar a conformação de uma espécie de turistofobia urbana, cujas principais críticas são endereçadas aos guiris: turistas estrangeiros que encarnam o estereótipo do visitante prejudicial ao presente e à construção do futuro de Barcelona. Guiri é um termo pejorativo utilizado por segmentos da população e da mídia catalã para reforçar uma imagem caricata de turista indesejado: homem, adulto, cheio de dinheiro no bolso e que não se importa em pagar altos valores por serviços de hospedagem, alimentação e programas culturais. Algumas variações do termo também visam caçoar dos turistas que circulam pelas praias (guiri playero) ou zonas monumentais de Barcelona (guiri urbano) travestindo roupas e/ou portando objetos que materializam o que consideram idiotismo turístico dos guiris: sandália de dedo, bermuda estampada, camiseta colorida, câmera fotográfica, aparelho celular da última moda, cartão de crédito na funda do celular... (cf. MONNET, 2001).

Em termos ainda mais particulares, as Figuras 3 e 4 registram um conjunto de exasperadas palavras estrategicamente pichadas na Carrer de Sostres, Baixada de la Glòria, bairro de La Salut, no Distrito de Gràcia. 
Figura 3 - Escadaria de acesso ao Parc Güell: espaço arquitetado por Antoni Gaudí em princípios do século XX e inaugurado em 1926

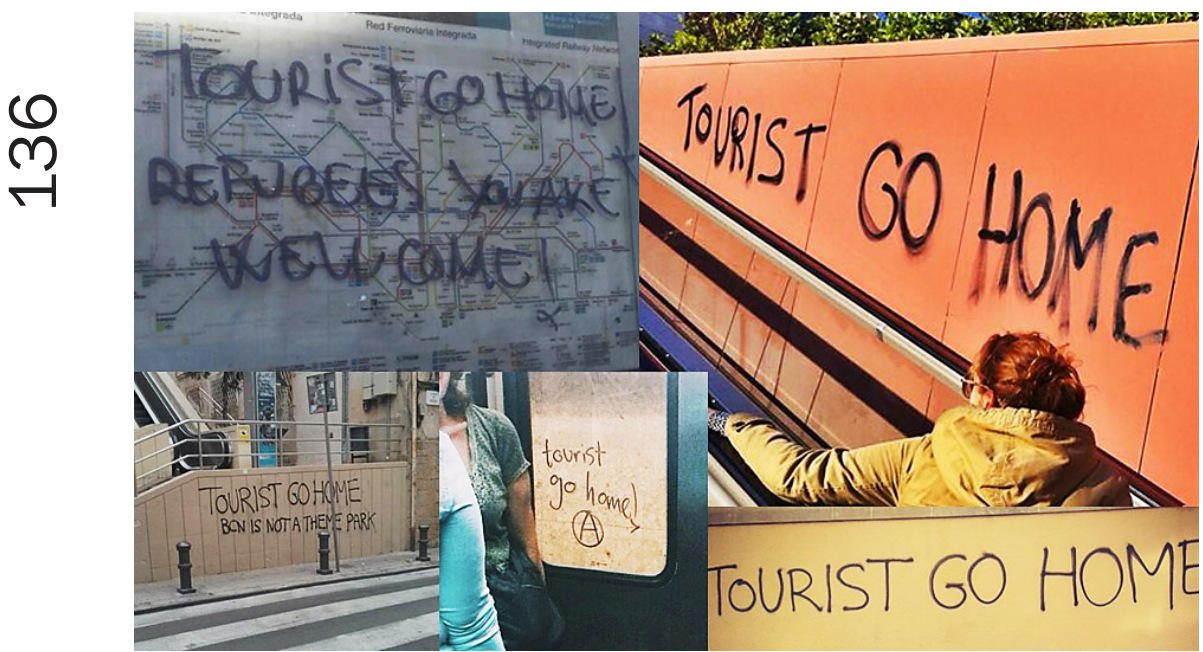

Fonte: Jordá (2015). Acervo dos autores, 2015.

Figura 4 - Poste de iluminação pública junto a uma das entradas do Parc Güell

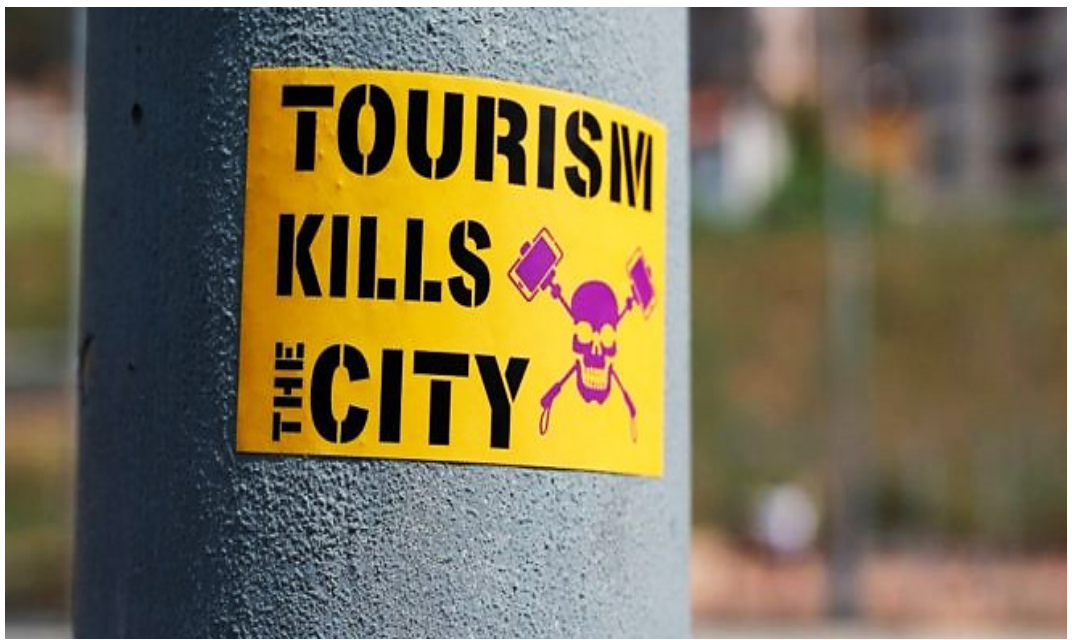

Fonte: Del Río (2017). 
Embora o Distrito de Gràcia seja marcado pela presença de antigos moradores - sobretudo pelo fato de La Salut, durante os anos 1960 e 1970, ter recebido programas governamentais voltados à construção de edifícios residenciais que posteriormente seriam vendidos à população com preços mais acessíveis do que os praticados pelo mercado imobiliário - a localidade foi convertida numa zona de passagem para muitos turistas que se interessam em conhecer o Parc Güell, um sítio monumental reconhecido como Patrimônio Mundial (https://parkguell.cat). Ao que tudo indica, a intensificação do fluxo de passantes pelo referido bairro remonta ao ano de 1984, momento em que a UNESCO oficialmente definiu que o Parc Güell atestava a "excepcional contribuição criativa de Gaudí para o desenvolvimento da arquitetura e da tecnologia de construção no final dos séculos XIX e início do XX" (UNESCO, 2017, tradução nossa).

\section{Figura 5 - Vista de parte da zona monumental do Parc Güell}

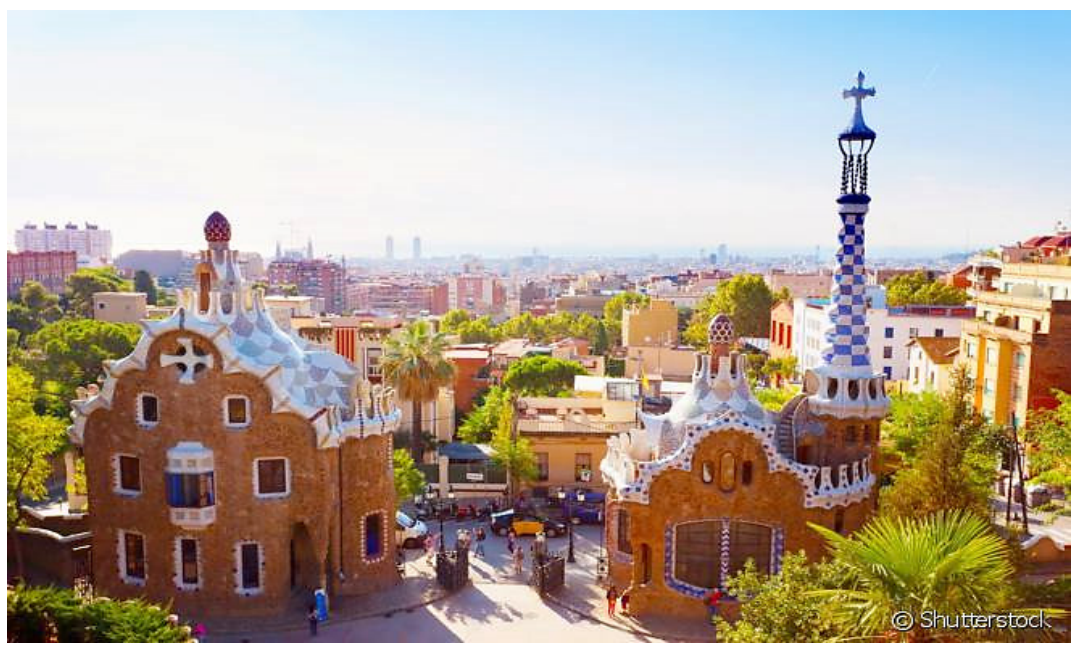

Fonte: Parc Güell (2016). Acervo dos autores. 
Em conjunto com outras sete obras de Antoni Gaudí, os monumentos do Parque também foram oficializados como patrimônios mundiais por "representarem um eclético, assim como muito pessoal, estilo que, com liberdade, ficou gravado no design dos jardins, esculturas e todas as artes decorativas, bem como na arquitetura" (UNESCO, 2017, tradução nossa).

Além dos movimentos que atuam contra o avanço do turismo, contestando a promoção internacional de Barcelona como um gigantesco e belíssimo cartão postal a céu aberto - aliás, um theme park, como demonstrado na Figura 3 - eles também usam o patrimônio para dar visibilidade e se posicionarem em relação a uma questão extremamente delicada para as sociedades europeias, qual seja: a recepção de estrangeiros em situação de vulnerabilidade, procedentes de países acometidos por violentos conflitos armados. Para além de exporem publicamente o desejo de que essas pessoas fixem moradia em Barcelona, esses movimentos aproveitam-se taticamente da visibilidade global do patrimônio da cidade para constranger não apenas o turista desavisado ou indiferente a esse tipo de debate, mas também as autoridades políticas responsáveis pelo governo de países associados à União Europeia, particularmente as lideranças do Partido Popular da Espanha (PP), cuja figura do primeiro-ministro, Mariano Rajoy (PP), corporifica o principal adversário da questão, uma vez que teria sido ele o responsável pela precarização das políticas e dos programas de recepção de refugiados desde que assumiu a presidência do governo em 2011. A Figura 6 é bastante significativa: 
Figura 6 - Imediações do bairro Gòtic, Cidade Velha, em Barcelona

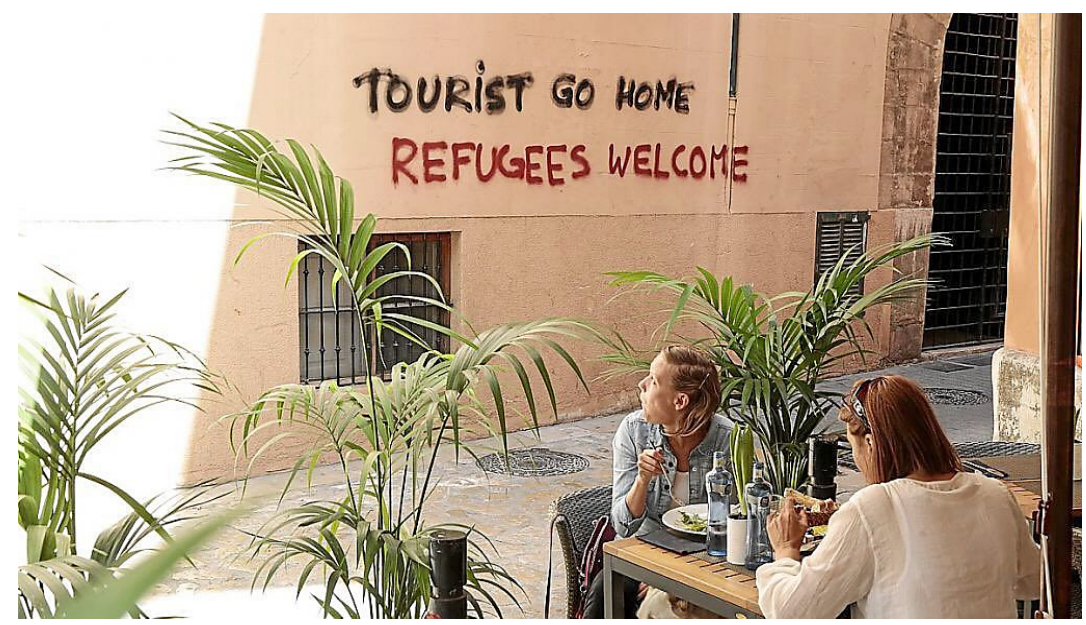

Fonte: Malagón (2017). Acervo dos autores.

Outro foco de atenção de sujeitos e/ou grupos que utilizam o patrimônio como recurso para críticas à expansão do turismo em Barcelona é ainda mais delicado: a suspeição que procura fazer equivalência dos turistas estrangeiros com os "terroristas internacionais" que, nas últimas décadas, perpetraram atos de violência contra a população residente de diversas capitais europeias. Londres, Paris e a própria Barcelona são apenas alguns exemplos de cidades que, desde 2015, foram vítimas de atos terroristas. E, mais do que isso, são cidades cujos habitantes convivem com a tensão de que um ato terrorista pode acontecer a qualquer momento, em situações cotidianas, tais como ao se tomar um metrô ou ao participar de um evento realizado em espaços públicos.

Deslocando esse debate em direção à crítica aos turistas que supostamente atuam de forma predatória, passou a ser comum encontrarmos nas zonas turísticas de Barcelona - sobretudo, junto à Cidade Velha e à entrada do Parc Güell - inscrições que registram palavras de insatisfação dos barceloníns para com a presença dos turistas na cidade. Em continuidade, apresentamos um painel com quatro imagens que ilustram quão delicada é a situação. 
Figura 7 - Zona de circulação turística junto à Cidade Velha, em Barcelona
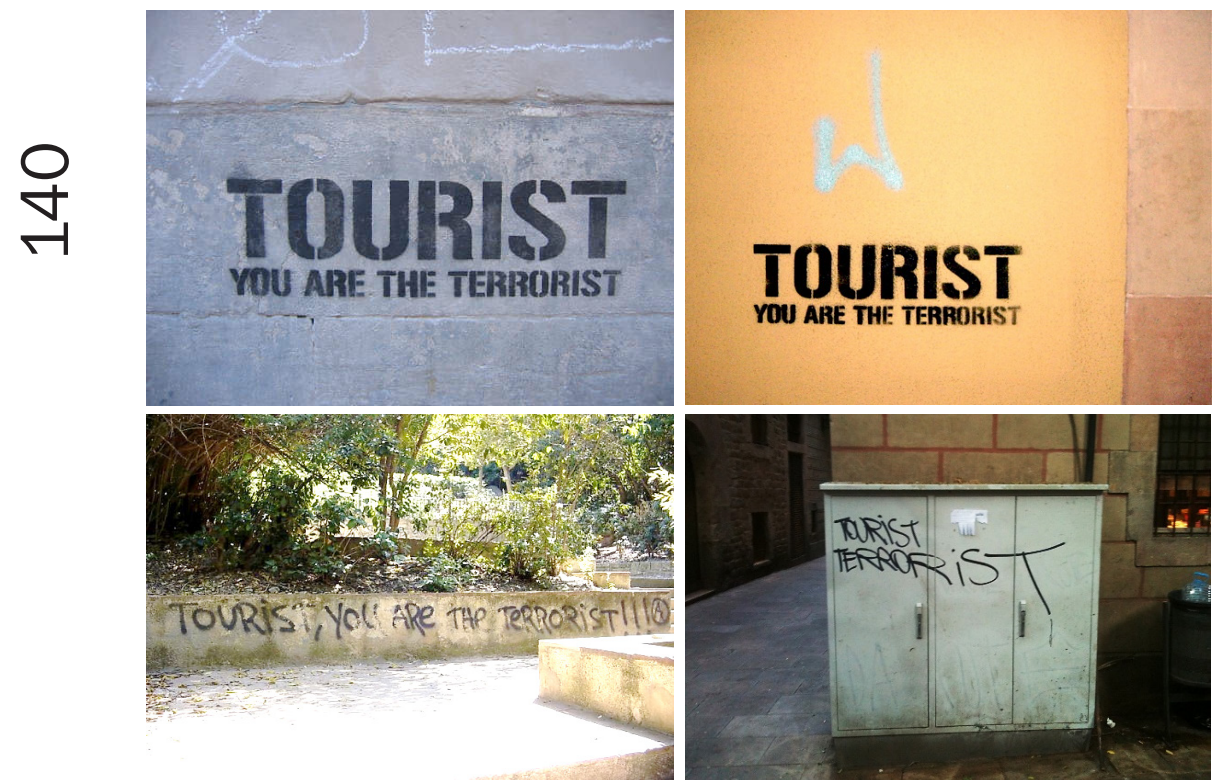

Fonte: Gomez-Moriana (2014) e Giacalone (2017). Acervo dos autores.

As quatros imagens são assaz interessantes. Para além de ácidas palavras de ordem, as pichações dão a pensar sobre as formas de organização e materialização da crítica ao turismo em Barcelona. As duas imagens que compõem a parte inferior do painel constituem-se em escritas vernaculares, feitas à mão livre, produzidas com tinta spray comercializada em diversas lojas da cidade. A inclinação levemente curva da frase, a ausência de um eixo estruturante para a composição e a variação na intensidade da cor preta de cada uma das letras conferem um caráter de informalidade à pichação, bem como sugerem que foram efetuadas de modo apressado, muito provavelmente por um transeunte que circulava pela região e a escolheu como um local adequado ao picho. Longe de um ato irrefletido, astutamente, as duas escritas grafam em espaços patrimoniais da cidade um conjunto de palavras que visam constranger o turista, em pleno momento de sua fruição citadina. Ao se expressarem 
por meio da língua inglesa, as pichações procuram assegurar o entendimento rápido e claro do endereçado e da mensagem, bem como evitar eventuais incompreensões devido ao desconhecimento dos idiomas mais comuns entre os moradores de Barcelona (Català e espanhol).

De outra ordem são as duas imagens que integram a parte superior do painel. Produzidas por meio da técnica do stencil (do francês pochoir), elas evidenciam intrincados procedimentos de preparação técnica que antecedem à pichação. Cumpre registrar que foi cuidadosamente selecionada a tipografia mais adequada, um papel de impressão com gramatura espessa, assim como o recorte e o local de perfuração do papel foram meticulosamente pensados para que, quando da aplicação da tinta spray, a pichação não ficasse borrada ou escorrida. A opção por uma tipografia sóbria, sólida, matematizada, com espaço entre as letras milimetricamente observados e a ausência de elementos que pudessem ornamentar a composição (arabescos, sublinhados, serifações etc.), sem dúvida, demonstram uma preocupação sofisticada para com a preparação técnica da pichação. No que tange à execução, esse tipo de pichação indica a aplicação metódica de conhecimentos tecnológicos para a fabricação de instrumentos portáteis de grafismo, tais como fôrmas de papel com dizeres de ordem (tourist: you are the terrorist), assegurando ao ato de picho certa serialização, rapidez, continuidade e simultaneidade no tempo e no espaço da cidade.

Frente ao que apresentamos até aqui, cabe-nos revolver mais uma vez as perguntas de Michel de Certeau (1996, p. 189): “depois de haver projetado a cidade futura, será que se começou a imaginá-la no passado”, passado este palatável para degustação turística? De nossa perspectiva, está cristalino que, em Barcelona, durante as décadas de 1980 e 1990, agentes públicos e privados investiram pesadamente na reabilitação de ícones do passado da cidade, objetivando adequá-los à exploração turística. Entre 1980 e 1982, período em que certos líderes políticos da Espanha decidiram oficializar a candidatura de Barcelona a sede dos jogos olímpicos de verão de $1992^{8}$, empresários e gestores governamentais passaram a investir em estratégias de ativação patrimonial, cujo resultado parece ter 
sido a conversão de bens culturais em ativos econômicos de elevada rentabilidade.

Longe de um mero efeito dessas políticas de exploração econômica do patrimônio, no mesmo transcurso, emergiriam em Barcelona numerosos movimentos que fizeram e vêm fazendo questão de demonstrar, publicamente, suas insatisfações para com o turismo e a presença de turistas considerados predatórios e indesejados à cidade, recorrendo a bens e lugares patrimonializados.

Foi considerando esse ponto de vista sobre o histórico desenvolvimento do turismo internacional na capital catalã que construímos a indagação que deu título à esta seção: Barcelona contra o turismo? Obviamente, responder a essa pergunta depende de pesquisas mais aprofundadas e comparativas. No entanto, as investigações que temos empreendido por meio de projetos em rede vinculados ao GPCCD apontam que a turistificação do patrimônio, ainda que se mostre economicamente rentável, tem suscitado problemas bastante complexos, o que torna o tema como ponto de uma agenda incontornável a ser enfrentada tanto por agentes governamentais e empresariais quanto por pesquisadores e estudiosos dos campos do patrimônio e do turismo.

O estudo que fizemos a respeito de Barcelona sinaliza também que os inusitados usos cotidianos do patrimônio cultural da cidade estão atravessados por temporalidades e espacialidades conflitantes, assim como mostra uma espécie de transbordamento da noção de patrimônio por força das disputas de consumo do passado, das manifestações de intolerância por suportadas pelos bens patrimonializados e, paradoxalmente, de expressões e pressões em prol do direito ao patrimônio e à própria cidade do presente e do futuro. Nesse âmbito, acreditamos que a questão "Barcelona contra o turismo?" coloca em discussão não apenas a necessidade de se repensar projetos que, dos gabinetes, utilizam bens e lugares patrimonializados como recursos turísticos para potencializar a cidade mercadoria. Para nós, o desafio aberto é rediscutir tanto o patrimônio na perspectiva de sua função-patrimônio quanto as complexas questões que emergem quando nos deparamos sobre como, para quem e com quem delinear as diretrizes projetuais que o associam ao turismo. 


\section{Considerações finais}

A cidade é um signo de identidade, um testemunho histórico das transformações sociais e econômicas e uma mostra de produção cultural. Barcelona, nesse sentido, é uma cidade transparente: seus bairros, seu crescimento, sua grande complexidade são, sem dúvida, um discurso sobre a própria história da cidade, sobre as tensões sociais em que viveu e, em última instância, a mais completa imagem do nosso passado remoto e recente (MARAGALL, 1981, p. 9, tradução nossa).

Recorremos a um discurso do alcaide de Barcelona, Pasqual Maragall, para concluir esta reflexão. As suas palavras nos parecem tão atuais quanto em 1981, ano em que foram publicadas como parte do texto de "Apresentação" do documento "Planos e Projetos para Barcelona: 1981/1982” (AJUNTAMENT DE BARCELONA, 1981, p. 5, tradução nossa). Após a dissolução das cortes franquistas em 1978, Maragall foi um político bastante envolvido com a retomada da democracia na Catalunha, atuando na defesa de eleições transparentes e democráticas para a Câmara Municipal de Barcelona. Aliás, foi esse processo eleitoral que o alçou ao cargo de prefeito de Barcelona para o período compreendido entre 1979 e 1982.

Como evidenciado por esse político, historicamente, Barcelona se constituiu como um terreno fértil para refletirmos sobre como a estética urbana pode sinalizar tensões sociais em torno dos usos do passado e da história da cidade. Nesse âmbito, esperamos que este artigo seja uma contribuição para todos aqueles que se interessam pelo estudo das formas de interação entre práticas urbanas que se apropriam do patrimônio cultural para reivindicar o direito à cidade como lugar de moradia e fruição de seus moradores, bem como para contestar a expansão de estratégias públicas e privadas que usam desse mesmo patrimônio para fortalecer projetos de turismo e alcançar metas econômicas de crescimento, convenientemente evocadas em nome do interesse público pela melhoria das condições de vida urbana. 
Para além disso, as análises que construímos nas páginas anteriores procuraram deixar claro que, desde a década de 1980, bens culturais ativados como patrimônios de Barcelona têm suportado um conjunto de conflitos urbanos em torno do crescimento vertiginoso do turismo internacional. Nessa direção, buscamos demonstrar que bens ativados como patrimônios mundiais têm servido de guarida para movimentos coletivos e/ou pessoas individuais que, à sua maneira, contrapõem-se aos modelos de turismo e à circulação de turistas na região. Utilizando (im)pertinentes palavras de ordem, esses movimentos se apropriaram do patrimônio para expressar suas críticas em relação a fenômenos urbanos delicados não apenas a Barcelona, mas também sensíveis em muitas de nossas cidades contemporâneas (violência, terrorismo, migrações internacionais, acolhimento ou recusa de refugiados, fluxos turísticos etc.).

Por fim, cabe ainda lembrar que o caso apresentado neste artigo sublinha uma questão importante para pesquisas interessadas nas aproximações entre patrimônio e turismo, qual seja: a necessidade de empreendermos reflexões mais aprofundadas a respeito de como se cruzam, no cotidiano das cidades, usos culturais, usos políticos e usos econômicos do patrimônio. Longe de compreender esses usos apartados uns dos outros, operados por agentes isolados, que pouco interagem entre si, parece-nos mais profícua a defesa de que é pela permutação desses usos que vem se configurando e se renovando o poder dos patrimônios e de suas funções na contemporaneidade.

\section{CULTURAL HERITAGE AND TOURISM: CONTEMPORARY TENSIONS}

Abstract: this article aims to reflect on the social tensions involved in the approximation between cultural heritage and tourism, focusing on recent events in the city of Barcelona. Based on a collection of sources concerning to two important tourist regions of that city (the monumental areas of the Parc Güell and the Old City), we try to problematize the ways and means by which the heritage has served as a support for contestations and reactions to the expansion of tourism in these regions. The article is divided into three parts. At first part, we present a theoretical discussion about the concepts and notions that we have mobilized in our recent researches and that help us in the debate about the disputes and tensions emerging from the tourist uses of 
places and heritages. At second, we seek to make an historical about the policies that guided the Barcelona urban changes and that implied in the patrimonialization and touristification of urban goods and places, as well as the ways in which they were appropriated to contest and interrogating their functions in the contemporaneousness of the city. In the last part, more than conclusions, we try to present some hypotheses that can subsidize new investigations on uses of the past and patrimonialization processes.

Keywords: Cultural heritage. Memory. Tourism. Contemporary city. Barcelona.

\section{Notas}

${ }^{1}$ Vinculado aos Departamentos de História, Design e Direito e ao Programa de Pós-graduação de Patrimônio Cultural e Sociedade da Univille, o GPCCD é composto por 22 estudantes e 16 pesquisadores, cuja atuação se dá em torno de duas linhas de pesquisa: a) patrimônio cultural, memória e cidade; b) patrimônio cultural, educação e tecnologia. Em parceria com colaboradores brasileiros, vinculados a universidades da região sudeste e sul do Brasil, e estrangeiros associados à Universidad Nacional de Villa María (Argentina) e à Universitat de Barcelona (Espanha) e Universidade de Coimbra (Portugal), o Grupo tem construído publicações em rede e se envolvido com a promoção de estudos e eventos científicos que visam promover diálogos epistemológicos entre diferentes campos disciplinares para enfrentar a complexidade e a multidimensionalidade de problemas que se desdobram das relações que diferentes sociedades do passado e do presente estabelecem com seus patrimônios culturais. No âmbito da extensão universitária, o GPCCD realiza, anualmente, oficinas, palestras e workshops que englobam temas e problemas emergentes de suas múltiplas interações com profissionais que atuam em espaços de memória, gestores públicos, professores e estudantes da educação básica, idosos, integrantes de organizações não-governamentais e movimentos sociais. Ainda nessa direção, o Grupo também tem efetuado trabalhos de consultoria histórica e cultural, a partir de demandas provenientes de órgãos públicos ou privados e de entidades coletivas da sociedade civil.

${ }^{2}$ Trata-se dos projetos "Usos e apropriações do patrimônio cultural nas cidades contemporâneas" e "Patrimônio cultural: entre redes e enredos", que tinham em comum o interesse pela investigação de processos de patrimonialização e usos do passado. No que tange à aproximação com a temática do turismo, as investigações apontaram que, na atualidade, as políticas de proteção e difusão de bens culturais em várias cidades brasileiras e estrangeiras são articuladas a 
políticas urbanas que vislumbram a turistificação do patrimônio e a patrimonialização para o turismo como saídas promissoras à resolução de problemas urbanos, principalmente, de ordem econômica. No âmbito desses dois projetos foram estudadas as seguintes cidades do sul do Brasil: Joinville, Brusque e Mafra, localizadas no estado de Santa Catarina; Curitiba e Morretes, no estado do Paraná. Na Colômbia, foi estuda a cidade de Bogotá. Em Espanha, a cidade de Barcelona. Ainda em andamento, encontra-se um estudo sobre o patrimônio mundial da cidade de Coimbra, em Portugal. Entre 2014 e 2017, esses projetos contaram com recursos captados em três fontes de financiamento: Fundo de Apoio à Pesquisa da Univille; Coordenação de Aperfeiçoamento de Pessoal de Nível Superior, por meio dos Programas de Doutorado Sanduíche no Exterior e de Suporte à Pós-Graduação de Instituições Comunitárias de Ensino Superior; Conselho Nacional de Pesquisa, por intermédio do Programa de EstudantesConvênio de Pós-Graduação.

${ }^{3}$ Em algumas publicações do GPCCD tornamos públicos os resultados de trabalhos acadêmicos por nós desenvolvidos com aportes da História Cultural, da História do Tempo Presente e da História Oral (ver: COELHO; PARRA, 2018; SOSSAI, 2017; BRESCIANO; SOSSAI, 2016; CHIANELLO; COELHO, 2016; COELHO; RADUN, 2016; SOSSAI; MENDES, 2016; COELHO; SOSSAI, 2011; 2014; 2016; FILHO; COELHO, 2015; MARQUES; COELHO, 2015; CASTRO; COELHO, 2014; COELHO; SOSSAI; MACHADO, 2013; COELHO, 2011).

${ }^{4}$ Sociólogo e geógrafo, Jordi Borja ocupou o cargo de diretor do "Programa de Descentralização e Participação Cidadã da Prefeitura de Barcelona (1983-1987) e da Área Metropolitana (1987-1990)". Também coordenou os trabalhos de elaboração do "Projeto da Carta Municipal de Barcelona (1989-1991)". Em 1991, tornou-se "delegado de relações exteriores e realizou numerosas assessorias para cidades da Europa e da América Latina". Além disso, foi "conselheiro (special adviser) da Conferência Habitat II (1996) e do Grupo 4+ (coordenação das organizações internacionais de cidades que se preparavam para a Assembleia Mundial de Cidades paralelamente à Conferência Habitat)" (BORJA, 1995, p. 8 , tradução nossa).

${ }^{5}$ Entre os vários trabalhos que estudam o processo de transformação da cidade em mercadoria, destacamos a obra de Fernanda Sánchez (2001). Segundo a autora, podemos identificar os prenúncios da formação de um mercado mundial de cidades nos anos de 1980 e sua intensificação na década seguinte. $\mathrm{Na}$ atualidade em que escrevia (2001), as políticas urbanas neoliberais continuavam em franca expansão, especialmente no Brasil. Dentre as estratégias utilizadas para caracterizar a cidade-mercadoria encontram-se iniciativas tanto de enobrecimento urbano que demandam segregação/distinção social no espaço, sob

Anos 90, Porto Alegre, v. 25, n. 48, p. 117-150, dez. 2018 
a justificativa de renovação ou revitalização de determinadas áreas, quanto de mercantilização de bens culturais, patrimonializados ou não, sob os quais a cultura e os processos culturais locais vão sendo reconfigurados na e pela economia de mercado.

${ }^{6}$ No final de 2009, a prefeitura de Barcelona optou por finalizar a Campanha e criar "um modelo mais simples", segundo o qual os assuntos pertinentes à reabilitação da cidade passariam a ser tratados pelo "Consórcio de Habitação de Barcelona”, constituído um ano antes por meio da Lei 22/1998 (Carta Municipal de Barcelona). Entre as atribuições desse Consórcio incluíam-se o "planejamento, a programação e a gestão de edifícios públicos em regime de aluguel” e a regulação das “ajudas específicas” destinadas à reabilitação de zonas de interesse do poder público (PARELLADA, 2012).

${ }^{7}$ A título de exemplos, citamos alguns escritos dessa natureza recentemente estudados no âmbito do GPCCD: Terán (1997); Capel (2009); Pascual-Molinas e Ribera-Fumaz (2009); Fernandes (2017).

${ }^{8}$ Para a tomada de decisão foi fundamental o apoio de duas lideranças políticas da Espanha. De um lado, os incentivos públicos de Joan Antoni Samaranch i Torrelló, um abastado empresário catalão, nascido em Barcelona, que, além de presidente do Comitê Olímpico Espanhol de 1966 a 1970, também foi presidente do Comitê Olímpico Internacional entre 1981 e 2000. E, de outra parte, as negociações políticas empreendidas por Felipe González Márquez, presidente da Espanha entre 1982 e 1996.

\section{Referências}

AJUNTAMENT DE BARCELONA. Plans i projectes per a Barcelona: 1981/1982. Barcelona: CEGE e Creaciones gráficas, 1981.

ARBOLÍ, Carles. La campanya 'Barcelona posa't guapa' ha rehabilitat en 25 anys un de cada tres edificis de la ciutat. Societat, Barcelona, $7 \mathrm{dez}$. 2010. Disponível em: <https://www.ara.cat/societat/barcelona-rehabilitacio-Hereu_0_385761828.html>. Acesso em: 10 nov. 2017.

BORJA, Jordi. La transformación urbana de Barcelona: velocidad y globalidad. Gestión urbana. Dossiê Barcelona: un modelo de transformación urbana, v. 4, p. 1-34, 1995.

Anos 90, Porto Alegre, v. 25, n. 48, p. 117-150, dez. 2018 
BRESCIANO, Juan; SOSSAI, Fernando (Org.). El conocimiento histórico en el ciberespacio: prácticas académicas y proyección social. Montevideo: Ediciones Cruz del Sur, 2016.

CAPEL, Horacio. El modelo Barcelona: un examen crítico. 2. ed. Barcelona: Serbal, 2009.

CASTRO, Alisson; COELHO, Ilanil. Tradição reembalada como espetáculo: reinvenção do ritual do Pelznickel em Guabiruba/SC. Blumenau em Cadernos, Blumenau, v. 6, p. 20-38, 2014.

COELHO, Ilanil. Pelas tramas de uma cidade migrante. Joinville: Editora Univille, 2011.

CHIANELLO, Marco Aurelio; COELHO, Ilanil. Entre preservar e renovar: uma análise da legislação urbanística de Joinville, Santa Catarina (1965-2015). Revista Confluências Culturais, v. 5, n. 1, p. 69-80, mar. 2016.

COELHO, Ilanil; PARRA, Daniel. Os mercados campesinos de Bogotá: patrimônio imaterial e desenvolvimento da economia campesina na Colômbia. Revista internacional interdisciplinar INTERthesis, v. 15, n. 1, jan./abr. 2018.

COELHO, Ilanil; RADUN, Denis. Tombamento, destombamento e retombamento: o jogo do patrimônio cultural no Brasil. In: BERND, Zilá; SANTOS, Nádia Maria Weber (Org.). Memória social: pesquisas e temas emergentes. Canoas, RS: Unilasalle, 2016. p. 27-44.

COELHO, Ilanil; SOSSAI, Fernando. Aproximações entre história pública e história oral: o caso do Laboratório de História Oral da Univille. Tempo e Argumento, Florianópolis, v. 9, p. 96-129, 2016.

. História oral, cidade e lazer no tempo presente. Revista História Oral, v. 17, p. 7-37, 2014.

COELHO, Ilanil; SOSSAI, Fernando; MACHADO, Diego. Un Fragmento de Sofia: lugares y prácticas de ocio en una ciudad brasileña contemporánea. In: GONZÁLEZ, Martha de Alba (Coord.). Vejez, Memoria y Ciudad: entre el derecho ciudadano y el recuerdo de la vida citadina en distintos contextos urbanos. México, DF: Casa Abierta, 2013. p. 109-133.

DE CERTEAU, Michel. Os fantasmas da cidade. In: CERTEAU, Michel de et al. $A$ invenção do cotidiano: morar, cozinhar. v. 2. Petrópolis: Vozes, 1996. p. 189-202.

DEL RÍO, Ignácio. Turistas, go home. A república, 10 ago. 2017.

FILHO, João Abeid; COELHO, Ilanil. Uma via em disputa: Rua do Príncipe, 1986 e 2004. Revista Confluências Culturais, v. 4, n. 2, p. 20-31, set. 2015.

Anos 90, Porto Alegre, v. 25, n. 48, p. 117-150, dez. 2018 
GIACALONE, Julien. When Barcelona bursts: tragedy of mass tourism in Barcelona. HEREYOUARE Paris, 18 nov. 2017. Disponível em: <http://hereyoua. re/paris/when-barcelona-bursts-tragedy-of-mass-tourism-in-barcelona-part-2/>. Acesso em: 7 dez. 2017.

GOMEZ-MORIANA, Rafael. Tourism versus Terrorism. Criticalista, 28 fev. 2014. GUPTA, Akhil; FERGUSON, James. Mais além da "cultura”: espaço, identidade e política da diferença. In: ARANTES, Antonio (Org.). O espaço da diferença. Campinas: Papirus, 2000. p. 30-49.

HEINICH, Nathalie. O inventário: um patrimônio em vias de desartificação? PROA: Revista de Antropologia e Arte, Campinas, n. 5, p. 1-13, 2014.

INE. Instituto Nacional de Estadística de España. España en cifras. Madrid: Índice, 2017.

. Estadística de Movimientos Turísticos en Fronteras (FRONTUR): datos provisionales. Madrid, jun. 2018, p. 1-6.

JORDÁ. Carmelo. La prensa internacional dice "adiós” a Barcelona por las pintadas "tourist go home”. Libre mercado, 13 ago. 2015.

LA PROVINCIA de Barcelona recibió un 3\% más turistas en 2017, hasta los 12 millones. Europa Press, Barcelona, 9 mar. 2018. Disponível em: <https://20minutos.es/noticia/3283845/0/provincia-barcelona-recibio-alrededor-12-millonesturistas-2017/\#xtor=AD-15\&xts=467263>. Acesso em: 10 jun. 2018.

LEDO, Wilson. Espanha bate recorde de turistas. Jornal de Negócios, 12 jan. 2017. MARINHO, Rosane. Turistas são o maior problema de Barcelona, apontam moradores: cidade recebe 8 milhões de visitantes, quatro vezes o total de sua população, e entra para a lista dos lugares que mais odeiam viajantes. Projeto Colabora, 5 ago. 2017.

MALAGÓN, Patricia. Barcelona y Mallorca piden cambiar turistas por refugiados. Mediterráneo digital, 29 jun. 2017.

MARAGALL, Pasqual. Apresentació. In: AJUNTAMENT DE BARCELONA. Plans i projectes per a Barcelona: 1981/1982. Barcelona: CEGE e Creaciones Gráficas, 1981. p. 9-10.

MARQUES, Bruno; COELHO, Ilanil. Grafias urbanas: o patrimônio profanado pela pichação. Profanações, Mafra, v. 2, p. 75-89, 2015.

MONNET, Nadja. Moros, sudacas y guiris, una forma de contemplar la diversidad humana en Barcelona. Scripta nova, n. 94, v. 58, p. 1-20, ago. 2001. 
OCKE, Marco A. de Moraes; IKEDA, Ana. Marketing de lugar: estado da arte e perspectivas futuras. Revista Adm., n. 4, v. 49, p. 671-683, out./dez. 2014.

PARC GÜELL (Barcelona, Espanha). Patrimônio mundial da UNESCO. Pure viagem, 6 abr. 2016.

PASCUAL-MOLINAS, Núria; RIBERA-FUMAZ, Ramon. Retail gentrification in Ciutat Vella, Barcelona. In: PORTER, Libby; SHAW, Kate (Edit.). Whose urban renaissance? An international comparison of urban regeneration strategies. Londres: Routledge, 2009. p. 180-190.

PARELLADA, Ángela Matesanz. El modelo de rehabilitación urbana en Barcelona. Re-hab, 12 abr. 2012.

PRATS, Llorenç. Antropología y patrimonio. Barcelona: Editorial Ariel, 1997.

SÁNCHEZ, Fernanda. A reinvenção das cidades na virada de século: agentes, estratégias e escalas de ação política. Rev. Sociol. Polít., Curitiba, v. 16, p. 31-49, jun. 2001.

SOSSAI, Fernando. Dez notas sobre uso de fontes na pesquisa histórica: sentidos, dilemas e desafios. Revista Confluências Culturais, Joinville, v. 6, p. 118-122, 2017. SOSSAI, Fernando; COELHO, Ilanil. Memórias do Jardim Sofia: cenas da cidade migrante. Joinville: Editora da Univille, 2011.

SOSSAI, Fernando; MENDES, Geovana. Tempo tecnológico: uma análise de narrativas orais sobre o uso de tecnologias digitais em escolas públicas de Santa Catarina. Revista História Oral, v. 19, p. 7-39, 2016.

TÈRAN, Fernando de. El plan general metropolitano de Barcelona en el contexto del urbanismo español de los setenta. Papers: regió metropolitana de Barcelona, n. 28, p. 55-61, nov. 1997.

UNESCO. Works of Antoni Gaudí. Disponível em: <http://whc.unesco.org/ en/list/320/>. Acesso em: 10 nov. 2017.

Recebido em: 02/04/2018

Aprovado em: 04/08/2018 